\title{
Determination of Ground Water Quality for Agriculture and Drinking Purpose in Sindh, Pakistan
}

\author{
Benish Nawaz Merani ${ }^{1,{ }^{*}}$, Saghir Ahmed Sheikh ${ }^{1}$, Shafi Muhammad Nizamani ${ }^{1}$, \\ Aasia Akbar Panhwar ${ }^{1}$ and Mahvish Jabeen Channa ${ }^{2}$ \\ ${ }^{1}$ Institute of Food Sciences and Technology, Sindh Agriculture University, Tandojam, Pakistan \\ ${ }^{2}$ Department of Nutrition and Food Technology, University of Sindh Jamshoro, Pakistan
}

\begin{abstract}
The study was conducted to assess the quality of ground water from different Talukas of district Tando Muhammad Khan for drinking and agriculture purpose. Water samples for determining the water quality were collected in one liter polyethylene bags by observing standard sample collection method. It was ensured that sample collection sites must be at least 500 feet away from each other. Physical and chemical parameters of ground and surface water samples such as $\mathrm{pH}$, Electrical Conductivity (EC), Turbidity, Colour, Taste, Odour, Alkalinity as $\mathrm{CaCO}_{3}$, Bicarbonate $\left(\mathrm{HCO}_{3}\right)$, Carbonate $\left(\mathrm{CO}_{3}\right)$, Calcium (Ca), Magnesium (Mg), Hardness, Sodium (Na), Potassium (K), Chloride (Cl), Phosphate $\left(\mathrm{PO}_{4}\right)$, Total Dissolved Solids (TDS) and Arsenic (As) were determined.

The study clarified that $\mathrm{pH}$ and odour was within the permissible limits in majority of samples whereas, Arsenic (As), Hardness, Sodium (Na), Total Dissolved Solids (TDS), Taste, Chloride (Cl) and turbidity were beyond the permissible limits set by WHO.

The groundwater status in Tando Muhammad Khan district, TDS in $50 \%$ samples, Chloride in $54.16 \%$ samples, Sulphate in $44.8 \%$ samples, Calcium in $38.5 \%$ samples, Sodium in $54.16 \%$ samples, hardness in $21.88 \%$ samples were beyond the WHO's permissible limits for human consumption.
\end{abstract}

Keywords: Ground water, physical composition, chemical composition.

\section{INTRODUCTION}

Groundwater is a vital source of drinking and irrigation water. It is estimated that water covers about 70 percent of the earth's total surface but only $0.3 \%$ of it can be used by human beings. This is increasingly the case due to the effects of population growth and climate change, which are causing severe stress to surface water supplies [1, 2] and due to lack of proper maintenance the water supply systems are incapable to run their full capacity [3] therefore, water quality monitoring program is necessary for preserving the fresh water resources [4] or otherwise the consumption of poor quality of water may cause the severe health related problems. It is estimated that about 5 million children died in developing countries due to intake of polluted water [5].

Groundwater is the major source of water for domestic, agricultural and industrial purposes in many countries. In Pakistan, water supply coverage through piped network and hand pumps is around $66 \%$ [6]. It is estimated that, in Pakistan, due to poor water quality all the diseases and the entire death ratio is reported as 30 and $40 \%$, respectively [7]. Diarrhea and water borne diseases are reported as the leading cause of death in

*Address correspondence to this author at the Institute of Food Sciences and Technology, Sindh Agriculture University Tandojam, Pakistan;

Tel: +92-3332711539; E-mail: benishmirani@gmail.com infants and children in the country while every fifth citizen suffers from illness and disease caused by the polluted water [8]. Unluckily, very less attention is being paid to drinking-water quality issues and increasing of quantity remains the priority focus of water supply agencies. Country lacks the monitoring programs of drinking-water quality as well as surveillance programs. Weak institutional arrangements; lack of well-equipped laboratories in combination with absence of a legal framework for drinking-water quality issues have aggravated the situation. Moreover, the public awareness regarding water quality issues is dismally [9].

Unchecked and untreated disposal of Industrial and municipal waste, excessive use of fertilizers and insecticides is deteriorating the already low quality surface and groundwater. Pakistan's per capita water availability has declined from 5,600 cubic meters at the time of independence to 1,200 cubic meters currently and expected to reach the threshold level of 1,000 cubic meters before 2010 or even in 2007 due to lack of water quality monitoring and information management [10].

In Pakistan, water remains a critical resource for sustained wellbeing of its citizens. Water pollution is increasing because of competition for multiple usage practices which in turn is becoming the major cause of water shortage in Pakistan. Polluted water intake 
directly or indirectly is creating many health related diseases. Pakistan is in the list of the most waterstressed countries in the world, a situation which is going to degrade into outright water scarcity (WB) [11].

In recent years, an increasing threat to ground water quality due to human activities has become of great importance [12, 13, 14 and 15], therefore reliable analytical measurements for determination of quality of water are necessary before consumption by human and used in agriculture. Thus, analytical water quality parameters are utmost important and are playing a key role for water quality assessment. The analytical parameters for assessment of water quality include $\mathrm{pH}$, EC, Turbidity, color, taste and odor. Among chemical parameters, the basic role in soil texture modification is played by Alkalinity, bicarbonate, carbonate, calcium and magnesium. The hardness of water is formed by sodium, potassium, chloride, sulphate, nitrate, methaemoglobinaemia, phosphorus and TDS, while among trace and ultra-trace elements; Lead, Arsenic, Iron, fluoride, chromium, manganese, molybdenum, nickel, Aluminum and selenium are determined [16].

The objective of this study is to determine the groundwater quality is suitable or unsuitable for drinking and agriculture purpose.

\section{METHODOLOGY}

\subsection{Area of Study}

According to the new government setup in June 2005, Taluka Tando Muhammad Khan is emerged as a new district on map of Sindh province with its Head quarter located at Tando Muhammad Khan Town/ City. It is spread over a geographical area of about 1733.99 square kilometers (428469 acres). It is located at height of $55 \mathrm{ft}$ above mean sea level and between 250 07 ' 28" N latitudes and 680 31' 59" E longitudes. In North of the district, Hyderabad and Tando Allahyar districts are located, Badin district lies on South and East, West boundary is shared by district Thatta and the river Indus flows through North-West (Figure 1).

The evaluation of water quality including Arsenic was carried out in each Union Council (UC) of District Tando Muhammad Khan, Sindh, Pakistan. Water samples for determining the water quality were collected in one liter polyethylene bottles by observing standard sample collection method. It was ensured that sample collection sites must be at least 500 feet away from each other. Before sample collection the bottles were washed and rinsed properly with distilled water so as to remove any possible contamination. Water samples were collected using one liter polyethylene bottles and standard methods for this purpose were adopted. After purging, the polyethylene bottles and their caps were washed with same water and then sample was collected in bottle for getting maximum accuracy in result.

The water quality parameters are mainly divided into following categories:

\subsection{Physical and Aesthetic Parameters}

Electrical Conductivity (EC), pH, Turbidity, Colour, Taste, Odour.

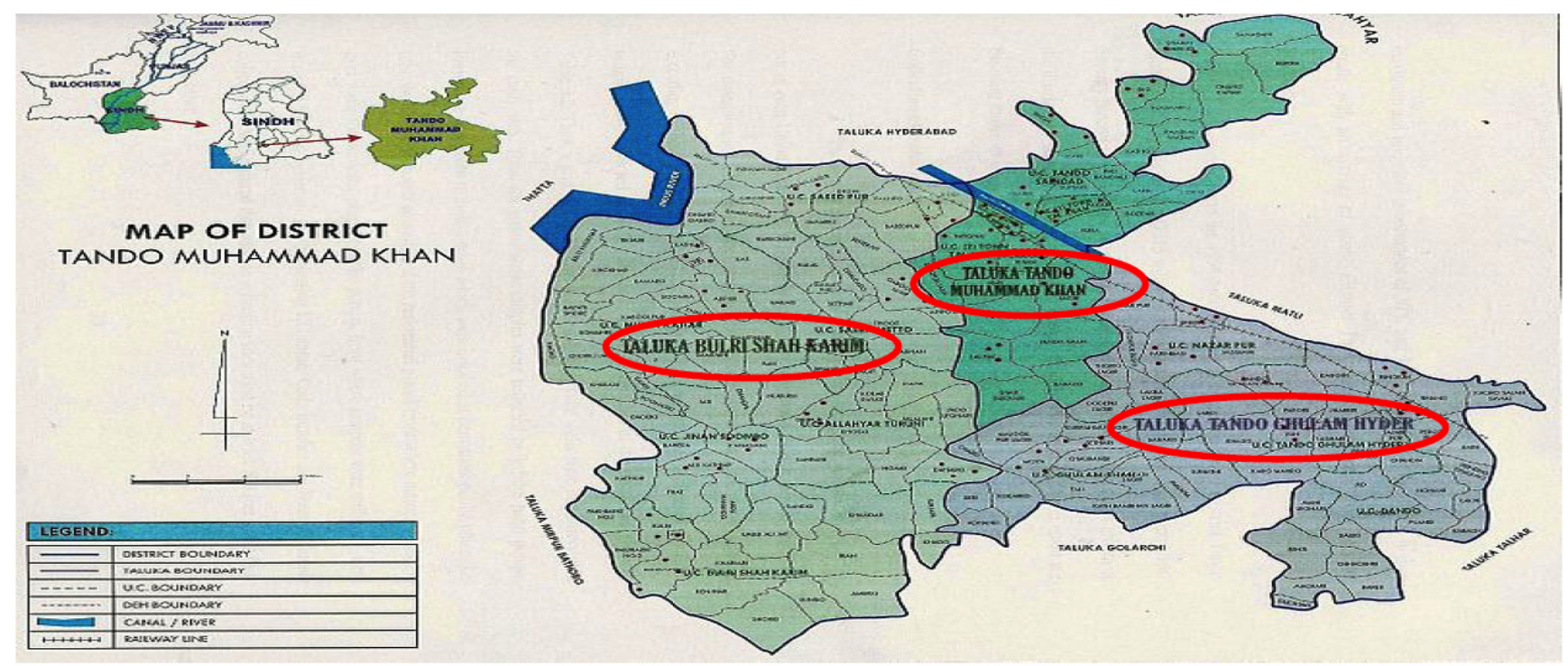

Figure 1: Tando Muhammad Khan ecological areas (Encircled the area of study: Taluka Tando Muhammad Khan, Taluka Tando Ghulam Hyder and Taluka Bulri Shah Karim). 


\subsection{Chemical Parameters}

Alkalinity as $\mathrm{CaCO}_{3}, \quad$ Carbonbate $\left(\mathrm{CO}_{3}\right)$, Bicarbonate $\left(\mathrm{HCO}_{3}\right)$, Calcium $(\mathrm{Ca})$, Magnesium $(\mathrm{Mg})$, Hardness, Sodium (Na), Potassium (K), Chloride $(\mathrm{Cl})$, Phosphate $\left(\mathrm{PO}_{4}\right)$, Total Dissolved Solids (TDS), Sodium Adsorption Ratio (SAR) and Residual Sodium Carbonate (RSC).

\subsection{Method Used to Investigate the Water Quality of Samples}

A detailed chemical analysis was carried out for each sample. In chemical analysis titration method was used for determining Anions $\left(\mathrm{CO}_{3}, \mathrm{HCO}_{3}\right.$ and $\mathrm{Cl}$ ), Cation ( $\mathrm{Ca}$ and $\mathrm{Mg}$ ), Alkalinity as $\mathrm{CaCO}_{3}$ and Hardness. Water quality parameters and methods used for analysis are given in Table 1.

\section{RESULTS AND DISCUSION}

The quality of groundwater in Pakistan and particularly in Sindh province is deteriorating fast due to varied causes. The study embodied in this paper aimed at determination of ground and surface water samples for $\mathrm{pH}$, Electrical Conductivity (EC), Turbidity, Colour, Taste, Odour, Alkalinity as $\mathrm{CaCO} 3$, Bicarbonate (HCO3), Carbonate (CO3), Calcium (Ca), Magnesium
(Mg), Hardness, Sodium (Na), Potassium (K), Chloride (Cl), Phosphate (PO4), Total Dissolved Solids (TDS) and Arsenic (As).

Number and percentage of groundwater samples with heavy metal levels and chemical composition beyond WHO's permissible limits in Taluka Tando Muhammad Khan is depicted in Table 2 and Figure 2. It was noted that TDS, Chloride, sulphate, calcium, sodium, turbidity, hardness and arsenic levels were higher than the WHO's permissible limit. Out of 36 samples of water TDS, Chloride, sulphate, calcium, sodium, turbidity, hardness and arsenic were observed higher in $10(27.78 \%, 13$ (36.11\%), 9 (25\%), 9 (25\%), 13 (36.11\%), 10 (27.78\%), 3 (8.33\%) and 23 (63.89\%), respectively. Similar results have also been reported from the neighbouring country (India) [17], who found $\mathrm{pH}$, EC, turbidity, TDS, alkalinity, total hardness, calcium, magnesium, sodium, potassium, chloride, nitrate, phosphate, sulfate and fluoride in excessive concentration and beyond the permissible limits of WHO. Taluka-wise position of groundwater samples determined for various heavy metals and other chemical composition showed relatively different trend [18]. In Taluka Tando Muhammad Khan odour, calcium and potassium were found within permissible limit of WHO in Taluka Tando Muhammad Khan.

Table 1: Water Quality Parmeters and Methods used for Analysis

\begin{tabular}{|c|c|c|}
\hline S. No. & Parameters & Test method \\
\hline 1 & Colour (TCU) & 15 units $(\mathrm{WHO})$ \\
\hline 2 & Odour & Odourless \\
\hline 3 & Taste (bitter, salty, sour and sweet) & Unobjectionable \\
\hline 4 & Alkalinity $\left(\mathrm{m} \cdot \mathrm{mol} / \mathrm{l}\right.$ as $\left.\mathrm{CaCO}_{3}\right)$ & 2320, Standard method (1992) \\
\hline 5 & Arsenic (mg/l) & Merck Test Kit (0-0.5 mg/l) 1.17927.0001 \\
\hline 6 & Bicarbonates & 2320, Standard method (1992) \\
\hline 7 & Carbonates (mg/l) & Standard method \\
\hline 8 & Calcium (mg/l) & 3500-Ca-D, Standard method (1992) \\
\hline 9 & Chlorides (mg/l) & Titration (Silver Nitrate), Standard Method (1992) \\
\hline 10 & Electrical Conductivity (micro S/cm) & E.C meter, Hach-44600-00, USA \\
\hline 11 & Hardness (mg/l) & EDTA Titration, Standard Method (1992) \\
\hline 12 & Magnesium (mg/l) & 2340-C, Standard Method (1992) \\
\hline 13 & $\mathrm{pH}$ at $25 \circ \mathrm{C}$ & pH Meter, Hanna Instrument, Model 8519, Italy. \\
\hline 14 & Phosphate (mg/l) & Method (Hach) $8190 \& 8048$ \\
\hline 15 & Potassium (mg/l) & Flame photometer PFP7, UK \\
\hline 16 & Sodium $(\mathrm{mg} / \mathrm{l})$ & Flame photometer PEP7, UK \\
\hline 17 & TDS $(\mathrm{mg} / \mathrm{l})$ & 2540C, Standard method (1992) \\
\hline 18 & Turbidity (NTU) & Turbidity Meter, Lamotte, Model 2008, USA \\
\hline
\end{tabular}


Table 2: Number and Percentage of Groundwater Samples with Heavy Metal Levels and Chemical Composition Beyond WHO's Permissible Limits in Taluka Tando Muhammad Khan

\begin{tabular}{|c|c|c|c|c|c|c|}
\hline S. No & Source & Parameter & Safe limit & $\begin{array}{l}\text { Total No. of } \\
\text { Samples }\end{array}$ & $\begin{array}{l}\text { No. of Samples beyond } \\
\text { permissible limit }\end{array}$ & $\begin{array}{c}\% \text { age beyond } \\
\text { permissible limit }\end{array}$ \\
\hline 1 & Hand Pump & $\begin{array}{l}\text { Taste (bitter, salty, sour } \\
\text { and sweet) }\end{array}$ & $\begin{array}{l}\text { Unobject- } \\
\text { ionable }\end{array}$ & 36 & 5 & 13.89 \\
\hline 2 & -do- & Colour & $15 \mathrm{TCU}$ & 36 & 10 & 27.78 \\
\hline 3 & -do- & Odour & Odourless & 36 & Unobjectionable & Nil \\
\hline 5 & -do- & $\begin{array}{l}\text { Total Dissolved Solids } \\
\text { (TDS) }\end{array}$ & $1000(\mathrm{mg} / \mathrm{l})$ & 36 & 10 & 27.78 \\
\hline 6 & -do- & Chloride $(\mathrm{Cl})$ & $250(\mathrm{mg} / \mathrm{l})$ & 36 & 13 & 36.11 \\
\hline 7 & -do- & Sulphate $\left(\mathrm{SO}_{4}\right)$ & $250(\mathrm{mg} / \mathrm{l})$ & 36 & 9 & 25 \\
\hline 8 & -do- & Calcium (Ca) & $75(\mathrm{mg} / \mathrm{l})$ & 36 & 9 & 25 \\
\hline 11 & -do- & Potassium (K) & $12(\mathrm{mg} / \mathrm{l})$ & 36 & Nil & Nil \\
\hline 12 & -do- & Turbidity (NTU) & $5 \mathrm{NTU}$ & 36 & 10 & 27.78 \\
\hline 13 & -do- & Hardness & $500(\mathrm{mg} / \mathrm{l})$ & 36 & 3 & 8.33 \\
\hline 14 & -do- & Arsenic (As) & 10 (ppb) & 36 & 23 & 63.89 \\
\hline
\end{tabular}

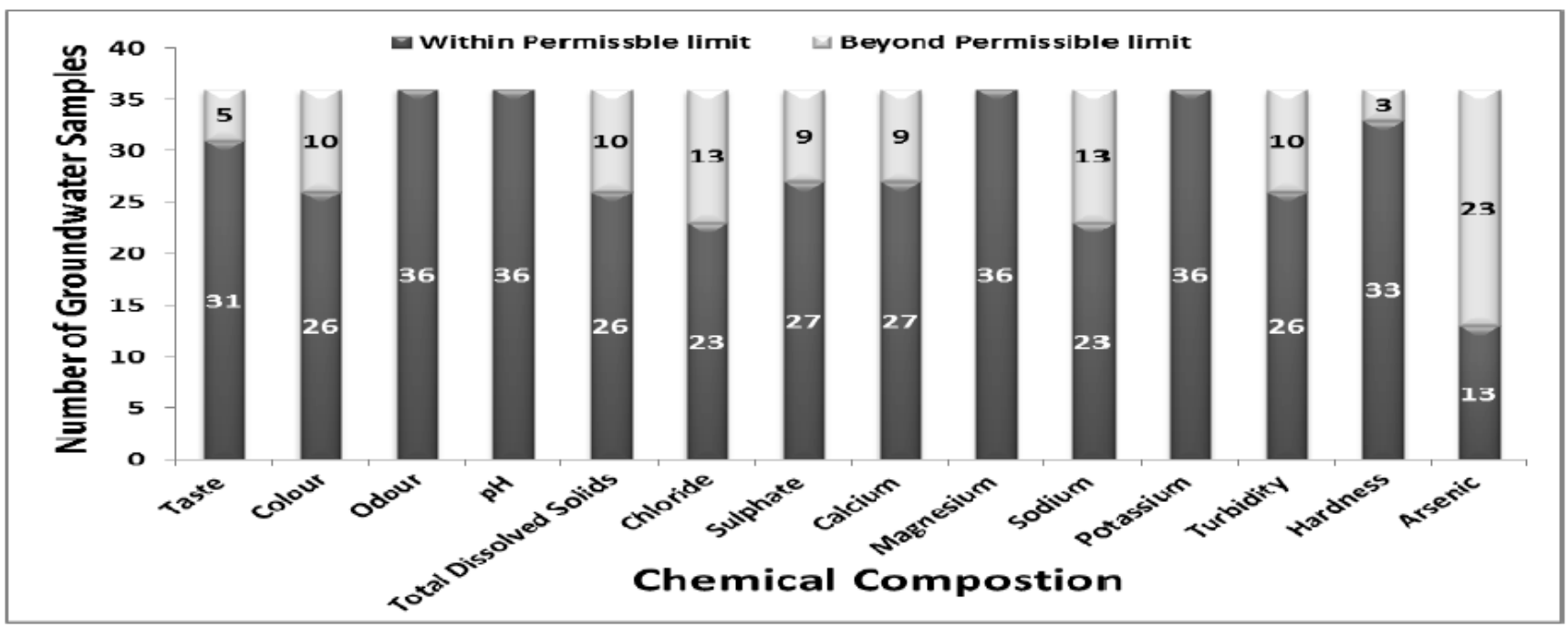

Figure 2: Chemical Composition of ground water in District Tando Muhammad Khan.

$\square$ Values above WHO Permissible Limits.

Values below/ Within WHO Permissible Limits.

Similarly, in Taluka Bulri Shah Karim the groundwater quality was not suitable for human consumption and particularly, the limits for taste, colour, TDS, chloride, sulphate, calcium, sodium, turbidity, hardness and Arsenic were well beyond the permissible limits of WHO for drinking purpose (Table 3 \& Figure 3). The arsenic level in 10 of samples was higher than the WHO's permissible limit of $10 \mathrm{ppb}$.
In Taluka Ghulam Hyder, the groundwater quality was relatively better than Tando Muhammad Khan and Bulri Shah Karim Talukas. However, limits for taste, TDS, chloride, sulphate, calcium, sodium and hardness and Arsenic were beyond the permissible limits of WHO for drinking purpose (Table 4 \& Figure 4).

The groundwater quality results of the present investigation are fully supported by llyas and Sarwar 
Table 3: Number and Percentage of Groundwater Samples with Heavy Metal Levels and Chemical Composition Beyond WHO's Permissible Limits in Taluka Bulri Shah Karim

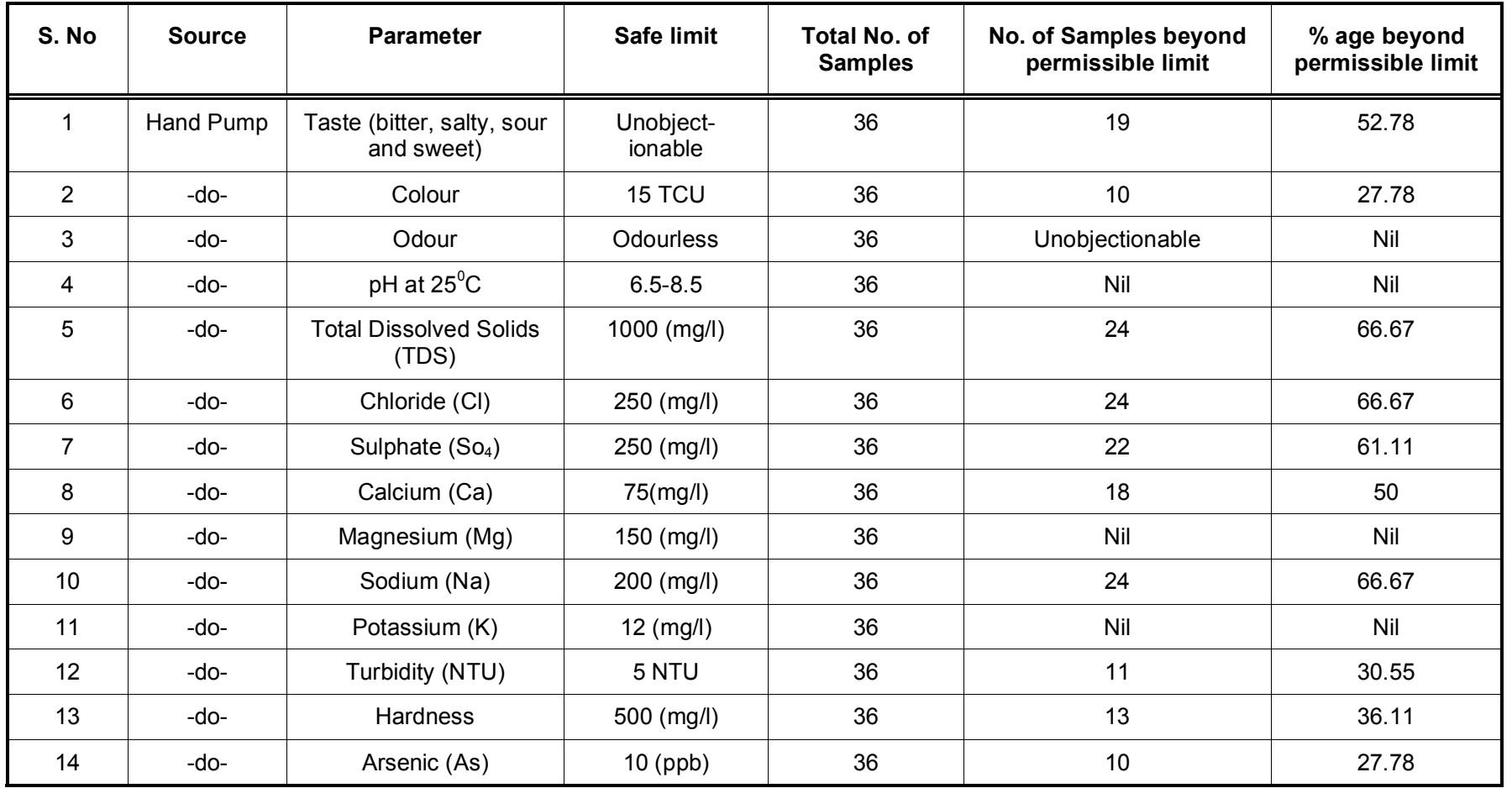

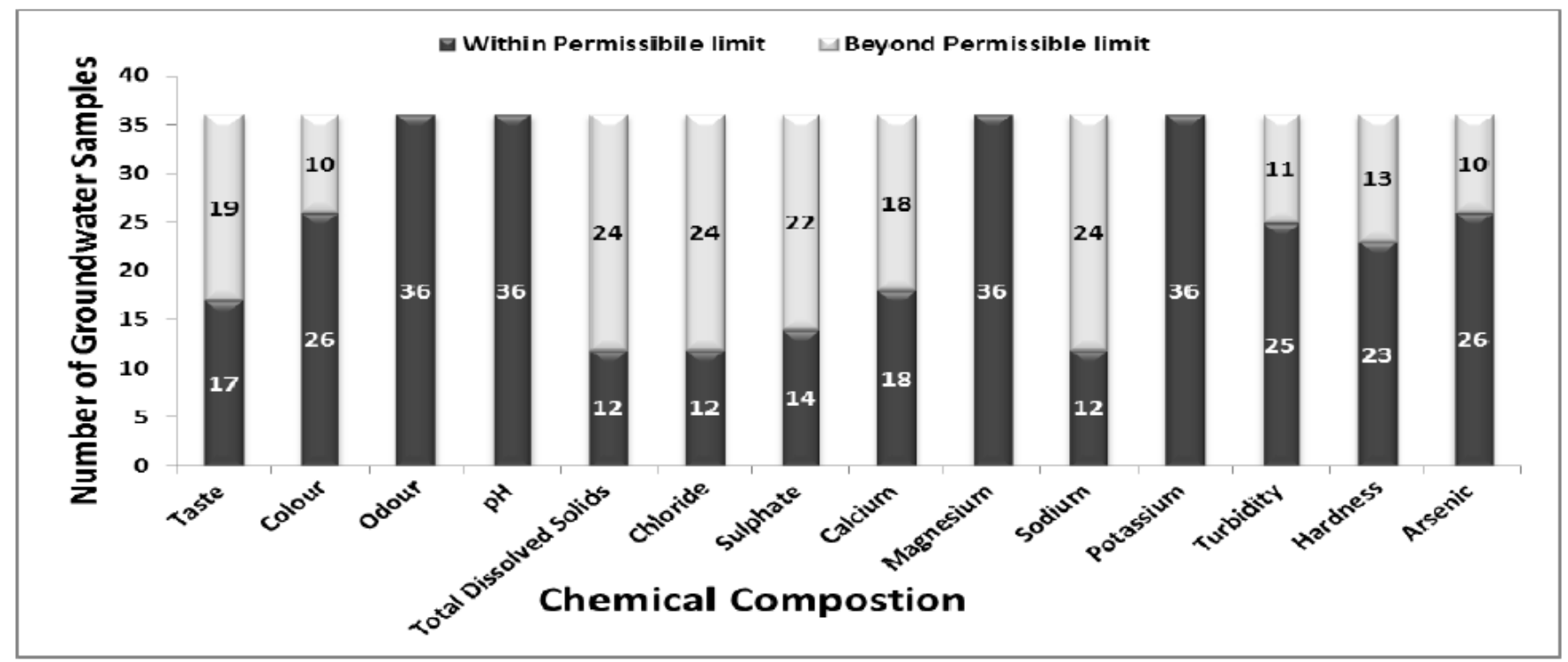

Figure 3: Chemical Composition of ground water in Taluka Bulri Shah Karim.

$\square$ Values above WHO Permissible Limits.

Values below/ Within WHO Permissible Limits.

[16] from Peshawar (Pakistan), who reported that $\mathrm{pH}$ and EC of drinking water were 7.8 and $0.62 \mathrm{dS} / \mathrm{m}$, drinking water had low turbidity and crossed the limit of $\mathrm{WHO}$ in some areas, while $\mathrm{Ca}$ and $\mathrm{Mg}$ (16.2 and 48.4 $\mathrm{mg} / \mathrm{l})$ were within the WHO limits. Similarly, in the present study, the odour, $\mathrm{pH}$, magnesium (Mg) and Potassium $(\mathrm{K})$ in majority of groundwater samples were within unobjectionable limits, and found safe for human consumption and for agricultural use. Thirumathal and Sivakumar from India [19], analyzed groundwater quality and found total dissolved solids (86-1165 mg/l), iron (0.6-4.1 $\mathrm{mg} / \mathrm{l})$, nitrates $(6.3-17.2 \mathrm{mg} / \mathrm{l})$, sulfates (4.9-32.5 $\mathrm{mg} / \mathrm{l})$, chlorides $(110-825 \mathrm{mg} / \mathrm{l})$, calcium (60.0-185.3 mg/l), magnesium (33.2-140.0 mg/l), 
Table 4: Number and Percentage of Groundwater Samples with Heavy Metal Levels and Chemical Composition Beyond WHO's Permissible Limits in Taluka Tando Ghulam Hyder

\begin{tabular}{|c|c|c|c|c|c|c|}
\hline S. No & Source & Parameter & Safe limit & $\begin{array}{l}\text { Total No. of } \\
\text { Samples }\end{array}$ & $\begin{array}{l}\text { No. of Samples beyond } \\
\text { permissible limit }\end{array}$ & $\begin{array}{l}\% \text { age beyond } \\
\text { permissible limit }\end{array}$ \\
\hline 1 & Hand Pump & $\begin{array}{l}\text { Taste (bitter, salty, sour } \\
\text { and sweet) }\end{array}$ & $\begin{array}{l}\text { Unobject- } \\
\text { ionable }\end{array}$ & 24 & 9 & 37.5 \\
\hline 2 & -do- & Colour & $15 \mathrm{TCU}$ & 24 & Nil & Nil \\
\hline 3 & -do- & Odour & Odourless & 24 & Unobjectionable & Nil \\
\hline 5 & -do- & $\begin{array}{l}\text { Total Dissolved Solids } \\
\text { (TDS) }\end{array}$ & $1000(\mathrm{mg} / \mathrm{l})$ & 24 & 15 & 62.5 \\
\hline 6 & -do- & Chloride $(\mathrm{Cl})$ & $250(\mathrm{mg} / \mathrm{l})$ & 24 & 15 & 62.5 \\
\hline 7 & -do- & Sulphate $\left(\mathrm{So}_{4}\right)$ & $250(\mathrm{mg} / \mathrm{l})$ & 24 & 12 & 50 \\
\hline 8 & -do- & Calcium (Ca) & $75(\mathrm{mg} / \mathrm{l})$ & 24 & 10 & 41.66 \\
\hline 11 & -do- & Potassium (K) & $12(\mathrm{mg} / \mathrm{l})$ & 24 & Nil & Nil \\
\hline 12 & -do- & Turbidity (NTU) & $5 \mathrm{NTU}$ & 24 & Nil & Nil \\
\hline 13 & -do- & Hardness & $500(\mathrm{mg} / \mathrm{l})$ & 24 & 5 & 20.83 \\
\hline 14 & -do- & Arsenic (As) & $10(\mathrm{ppb})$ & 24 & 1 & 4.17 \\
\hline
\end{tabular}

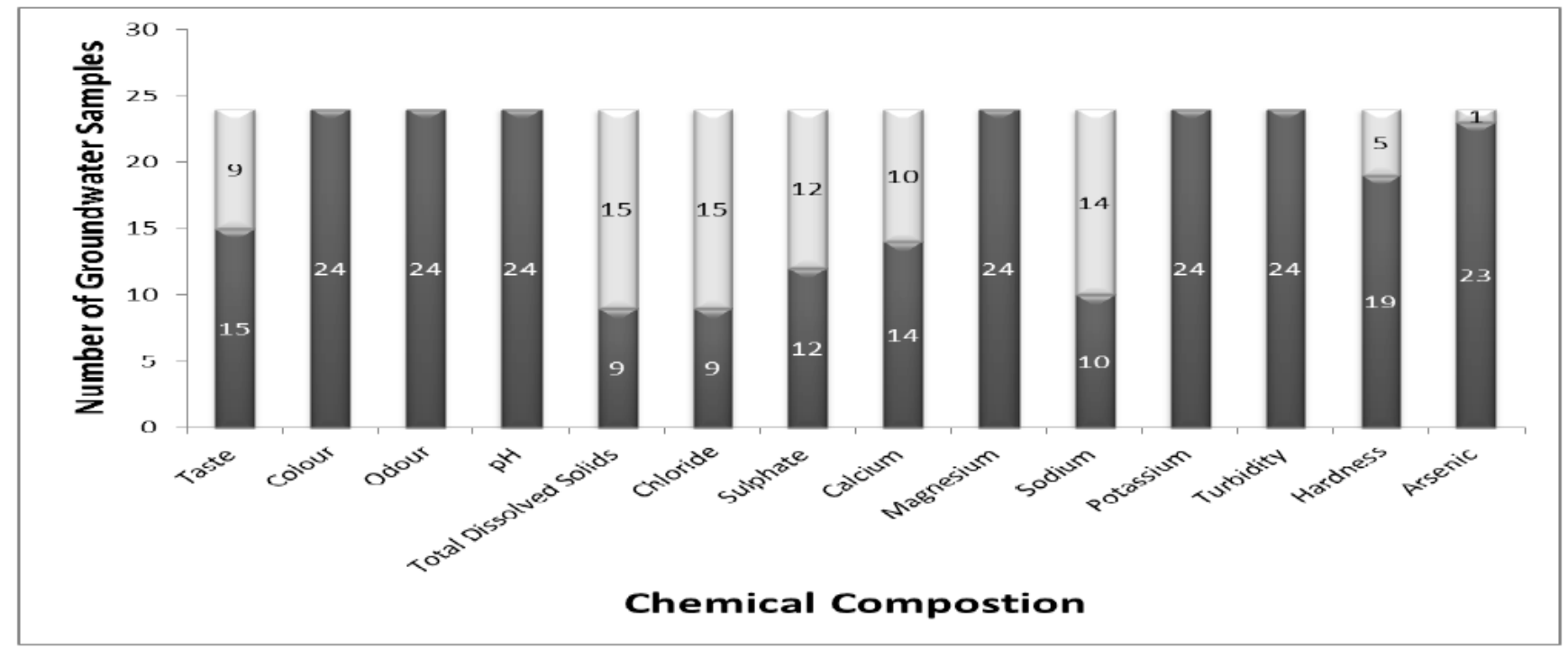

Figure 4: Chemical Composition of ground water in Taluka Tando Ghulam Hyder.

$\square$ Values above WHO Permissible Limits.

Values below/ Within WHO Permissible Limits.

biochemical oxygen demand (6.2-22.0 $\mathrm{mg} / \mathrm{l})$ and chemical oxygen demand (18-38.5 mg/l) in all the selected water samples. The findings of the present study are also in concurrence with Chaudhary et al. [20], who reported $\mathrm{pH} 7.2-7.8$, salinity $224-674 \mathrm{mg} / \mathrm{l}$, total dissolved solids (TDS) $1.0-1.96 \mathrm{mg} / \mathrm{l}$, hardness 292-560 mg/l, chloride $124-373 \mathrm{mg} / \mathrm{l}$, sodium $33-360$ $\mathrm{mg} / \mathrm{l}$, potassium 30-165 mg/l, magnesium 31-97 mg/l and sulfate $20.5-40.3 \mathrm{mg}$ and levels were highest in hand pump water.

In a recent study carried out by Naeem et al. [21] in Lahore (Pakistan), it was found that about $10-20 \%$ samples of the study area crossed the maximum permissible limit for TDS, hardness, calcium, magnesium, sulphate and fluoride while $20-30 \%$ 
samples crosses the limit for nitrate. The groundwater of the study area has also been classified to study various hydro chemical processes. Similarly, from Egypt, Saleh et al. [22] found that total dissolved solids (TDS) ranged from $390-8840 \mathrm{mg} / \mathrm{l}$ and the TDS, $\mathrm{pH}$ and water types with some minor differences between clusters.

\section{CONCLUSION}

It was concluded that TDS, Chloride, Sulphate, Calcium, Sodium, hardness and arsenic were beyond the WHO (PCRWR, 2002) permissible limits in majority of samples obtained from Taluka Tando Muhammad Khan, Bulri Shah Karim and Tando Ghulam Hyder. However, odour, pH, Magnesium (Mg) and Potassium $(\mathrm{K})$ in the groundwater samples were within unobjectionable limits.

The groundwater with TDS, Chloride, Sulphate, Calcium, Sodium and hardness beyond WHO's permissible limits which may not be used for drinking and irrigating crops.

It is recommended that without testing from recognized soil and water testing laboratory, the groundwater may not be used for drinking and agricultural use.

\section{REFRENCES}

[1] Edmunds WM. Renewable and non-renewable groundwater in semi-arid regions. Develop Water Sci 2003; 50: 265-80. http://dx.doi.org/10.1016/S0167-5648(03)80023-0

[2] Packialakshmi S, Ambujam NK. A hydrochemical and geological investigation on the Mambakkam mini watershed, Kancheepuram District, Tamil Nadu, Environ Monit Assess 2011.

http://dx.doi.org/10.1007/s10661-011-2189-1

[3] Biswas R, Khare D, Shaankar R. Water Management in Delhi: Issues, Challenges and Options. J Ind Water Works Assoc 2007; 39(2): 89-96.

[4] Pesce SF, Wunderlin DA. Use of water quality indices to verify the impact of Cordoba city (Argentina) on Suquia river. Water Res 2000; 34: 2915-26.

http://dx.doi.org/10.1016/S0043-1354(00)00036-1
[5] Holgate G. Environmental and Waste Management. 2000; 3: 105-12.

[6] Government of Pakistan. Pakistan Millennium Development Goals Report. Planning Commission 2008; 75: 2008.

[7] Government of Pakistan. Global Water Partnership. Draft South Asia - Water Vision 2025, Country Report 2000.

[8] Kahlown MA, Tahir MA, Rasheed H, Bhatti KP. Water Quality Status, National Water Quality Monitoring Programme, Fourth Technical Report. Pakistan Council of Research in water Resources 2006.

[9] Aziz JA. Eastern Mediterranean Health Journal 2005; 11 : 1087-98.

[10] PCRWR. Pakistan Council of Research in Water Resources (PCRWR) 2006-2007. Water Quality Report, Government of Pakistan, Islamabad 2007.

[11] WWF. Water \& health related issues in Pakistan 2007

[12] PCRWR. Pakistan Council of Research in Water Resources (PCRWR) 2004-2005. Water Quality Report, Government of Pakistan, Islamabad 2005.

[13] Ravikumar P, Somashekar RK. Multivariate analysis to evaluate geochemistry of groundwater in Varahi river basin of Udupi in Karnataka (India). The Ecoscan 2010; 4(2\&3): 15362.

[14] Aher KR. Groundwater Quality Studies of Chikalthana area of Aurangabad, Ph.D thesis submitted to Dr. B.A. Marathwada University, Aurangabad (MS) India 2012.

[15] Deshpande SM, Aher KR. Evaluation of Groundwater Quality and its Suitability for Drinking and Agriculture use in Parts of Vaijapur, District Aurangabad, MS, India. J Chem Sci 2012; 2(1): 25-31.

[16] Ilyas A, Sarwar T. Assessment of physico-chemical and biological quality of drinking water in the vicinity of Palosi drain Peshawar. Pak J Appl Sci 2003; 3(1): 58-65.

[17] Kaushik A, Kumar K, Kanchan, Tarun, Sharma HR. Water quality index and suitability assessment of urban ground water of Hisar and Panipat in Haryana. J Environ Biol 2012; 23(3): 325-33.

[18] PCRWR. Water quality status in Pakistan, Publication No. 11 2002, describing permissible limits of various water quality parameters in drinking water by WHO 2012.

[19] Thirumathal K, Sivakumar AA. Ground water quality of Swaminathapuram, Dindigul District, Tamil Nadu. J Ecotoxicol Environ Monitoring 2003; 13(4): 279-83.

[20] Chaudhary S, Anuradha, Sastry KV. Ground water quality in Faridabad, an industrial town of Haryana. J Ecotoxicol Environ Monitoring 2005; 15(3): 263-71.

[21] Naeem M, Khan K, Rehman S, Iqbal J. Environmental assessment of ground water quality of Lahore Area, Punjab, Pakistan. J Appl Sci 2007; 7(1): 41-46.

http://dx.doi.org/10.3923/jas.2007.41.46

[22] Saleh A, Al-Ruwiah FM, Shehata M. Ground-water quality of the Nile west bank related to soil characteristics and geological setting. J Arid Environ 2001; 49(4): 761-84. http://dx.doi.org/10.1006/jare.2001.0793

\section{DOI: http://dx.doi.org/10.6000/1927-5951.2014.04.02.2}

(c) 2014 Merani et al.; Licensee Lifescience Global.

This is an open access article licensed under the terms of the Creative Commons Attribution Non-Commercial License (http://creativecommons.org/licenses/by-nc/3.0/) which permits unrestricted, non-commercial use, distribution and reproduction in any medium, provided the work is properly cited. 